\title{
1971 PROGRAM
}

\section{AMERICAN SOCIETY FOR \\ CLINICAL INVESTIGATION, ING.}

63RD ANNUAL MEETING

Including programs for

American Federation for Clinical Research, Inc.

The Association of American Physicians

MONDAY, MAY 3

PENNSYLVANIA ROOM, HADDON HALL

ATLANTIC CITY 


\title{
American Society for Clinical Investigation, Inc.
}

\author{
63RDANNUAL MEETING
}

MONDAY, MAY 3

\author{
M OR N I N G \\ 9:00 a.m., Pennsylvania Room, Haddon Hall \\ FIRST BUSINESS SESSION \\ THE PRESIDENT'S ADDRESS \\ SCIENTIFIC SESSION
}

Chairman: Dr. Halsted R. Holman

(The presentation of each paper will be limited to 10 min.)

1. Gastrin Supersensitivity in the Pathogenesis of Lower Esophageal Sphincter Hypertension in Achalasia. S. Cohen,* W. Lipshutz,* and W. Hughes,* Philadelphia, Pa. (introduced by A. S. Relman**). (66)

2. On the Structure and Function of $Y$ Protein. G. Fleisch ner,* S. Mishkin,* H. Reyes,* J. Robbins,* A. J. Levi,* Z. Gatmaitan,* and I. M. Arias, New York. (103)

3. Stimulation of Hepatic Collagen Formation by Ethanol Consumption. L. FeinmaN* and C. S. Lieber, New York. (93)

4. Amyloidosis: a Disease Associated with Tissue Deposition of Fragments of Homogeneous Immunoglobulins. G. G. Glen Ner,* W. D. Terry,* C. Isersky,* D. Page,* and M. Harada,* Bethesda, Md. (introduced by J. L. Fahey**). (119)

5. Platelet Binding Antibodies Produced in Vitro by ITP Spleens. R. McMillan,* R. Longmire,* R. YelenoSKY,* and C. G. CRAddock,** La Jolla, Calif. (218)

6. Host Factors in Dissemination of Herpes Zoster. D. A. Stevens* and T. C. Merigan, Stanford, Calif. (296)

* Denotes nonmember, ASCI, AFCR, or AAP.

** Denotes emeritus member ASCI or senior member AFCR.

Names with no following symbol are active members of the society to which the abstract was submitted.

( ) Abstract number.

$\ddagger$ The President gratefully acknowledges the valuable assistance of the Subsection Chairmen in the selection of this program.
7. Immunologic Activation of Hageman Factor and Its Relationship to Fibrinolysis, Bradykinin Generation, and Complement. A. P. Kaplan,* I. Gigli,* and K. F. Austen, Boston, Mass. (170)

8. Isolation of Phagocytic Vesicles from Granulocytes and Macrophages. T. P. Stossel,* T. D. Pollard, R. J. Mason,* and M. Vaughan, Bethesda, Md. (298)

9. Specific Chemical-Enzyme Mediation of Tobacco Smoke Toxicity for Pulmonary Alveolar Macrophages (PAM). G. M. Green, G. M. Powell,* and T. G. Morris, Burlington, Vt. (131)

10. Molecular Basis of Gouty Inflammation. G. Weissmann, G. Rita,* and R. B. Zurier,* New York. (334)

11. Further Observations on the RNA- and DNA-Dependent DNA Polymerases of Normal and Leukemic Cells and Selective Inhibition by Rifamycin Derivatives. G. Smith,* S. Yant,* F. Herrera,* J. Whant-Peng,* and R. Gallo,* Bethesda, Md. (introduced by C. G. Zubrod**). (287)

12. Studies on Mechanism of the Neural Lesion of Pernicious Anemia. E. P. Frenkel,* Dallas, Tex. (introduced by E. Strauss**). (111)

\section{A FTERNOON}

2:00 p.m., Pennsylvania Room, Haddon Hall

\section{SECOND BUSINESS SESSION}

\section{SCIENTIFIC SESSION}

Chairman: Dr. Kurt J. Isselbacher

13. Insulin-Receptor Interactions in Adipose Cells. P. CuATRECASAS,* Baltimore, Md. (introduced by V. A. McKusick**). (73)

14. First Step in Insulin Action: Direct Study of Binding to Liver Receptors. P. Freychet,* J. Roth, and D. Neville,* Bethesda, Md. (112)

15. Genomic Recognition of Hormone-Receptor Complexes: a General Concept for Steroid Hormones. A. W. Steggles,* T. C. Spelsberg,* and B. W. O'Malley, Nashville, Tenn. (292)

16. Ectopic Adenyl Cyclase Receptors in Endocrine Tumors. I. ScHORR* and R. L. NeY, Chapel Hill, N. C. (273) 
17. Aldosterone and the Fatty Acid Composition of Toad Bladder Phospholipids. D. B. P. Goodman,* J. E. ALLEN,* and H. Rasmussen, Philadelphia, Pa. (127)

18. Effects of Aldosterone, Vasopressin, Ouabain, and Amiloride on an Epithelial Cell Preparation from the Toad Urinary Bladder. J. S. Handler, A. S. Preston,* and J. Orloff, ${ }^{* *}$ Bethesda, Md. (141)

19. Mechanism of Thyroid Calorigenesis: Role of Activation of NaK-ATPase. F. IsmaIL-Beigi* and I. S. EdelMan,** San Francisco, Calif. (157)

20. Control of Parathyroid Secretion in Primary Hyperparathyroidism. T. Murray,* M. Peacock,* D. Powell,* R. Neer,* L. Deftos,* and J. Potts, JR., Boston, Mass. (330)
21. Evidence for a Common Saturable Removal System for Dietary and Endogenous Triglyceride in Man. J. D. Brunzell,* D. Porte, Jr., and E. L. Bierman, Seattle, Wash. (48)

22. Characterization of Myocardium Revascularized by Aorto-to-Coronary Artery Bypass Grafts. F. J. KLockE, G. Schimert,* I. L. Bun nell,* D. G. Greene,* S. M. Wittenberg,* and T. Lajos,* Buffalo, N. Y. (182)

23. Dependence of Tension in Heart Muscle on the Resting Potential. H. Fozzard* and R. Gibbons,* Chicago, Ill. (introduced by L. B. Sorensen). (108)

24. Mannitol Reversal of "No-Reflow" After Renal Ischemia. J. Flores-Calle,* C. H. Beck, JR.,* D. R. Di Bona,* C. Marcilio,* and A. Leaf,** Boston, Mass. (105)

\title{
Joint Program with the
}

\section{American Federation for Clinical Research, Inc.}

\author{
SUNDAY AFTERNOON, MAY 2
}

\section{CARDIOVASCULAR PHYSIOLOGY}

2:00 p.m., Pennsylvania Room III, Haddon Hall

Co-Chairmen: Dr. Andrew Wallace

Dr. Richard Crout

1. A Thirty-Year Study of Blood Pressure in a White Male Cohort. W. R. Harlan, A. Oberman,* R. W. Mrtchell,* and A. Graybiel,* Birmingham, Ala., and Pensacola, Fla. AFCR

2. Decreased Human Systolic Blood Pressure in Essential Hypertension by Operant Conditioning. H. BENSON,* D. Shapiro,* B. Tursky,* and G. E. Schwartz,* Boston, Mass. (introduced by W. H. Abelmann**). ASCI (23)

3. Significance of Precise Determination of Basal Plasma Renin in Primary Aldosteronism. J. R. Stockigt,* R. D. Collins,* C. A. Noakes,* and E. G. Biglieri, San Francisco, Calif. ASCI (297)

4. The Effect of Methyldopa on Plasma Renin Activity in Dogs. S. Mohammed and P. J. Privitera,* Cincinnati, Ohio. AFCR

5. Identification and Characterization of the Cardiac $\beta$ Adrenergic Receptor. R. Lefkowitz* and E. HABER, Boston, Mass. ASCI (193)

6. New Methods for the Study of Myocardial Hypertrophy. E. Page, Chicago, Ill. ASCI (243)

7. Inefficient Energy Utilization in Experimental Congestive Heart Failure. H. N. Coleman and J. F. GunNING,* Rochester, Minn. AFCR
8. Familial Left Axis Deviation, Right Bundle Branch Block and Complete Heart Block: A Heritable Disorder of Cardiac Conduction. S. SchaAl,* J. Seiden-Sticker,* R. Goodman,* and C. Wooley,** Columbus, Ohio. AFCR

9. The Myocardial Effect of Diuretic Drugs. R. H. Seller, S. Banach,* M. Neff,* T. Namey,* and C. Swartz, Philadelphia, $\mathrm{Pa}$. AFCR

10. Idiopathic Orthostatic Hypotension. H. A. Kontos, D. W. Richardson, and J. E. Norvell,* Richmond, Va. ASCI (185)

11. Aortocoronary Bypass Graft: Preoperative Assessment and Early Followup. Y. Kong, V. S. BEHAR,* R. H. Peter,* and J. J. Morris, Jr., Durham, N. C. AFCR

\section{DERMATOLOGY}

\section{2:00 p.m., West Room, Haddon Hall \\ Co-Chairmen: Dr. Arthur Eisen Dr. Leonard Harber}

1. Solubilization and Fractionation of Epidermal Proteins. J. H. Herndon, Jr., Dallas, Tex. AFCR

2. Defective Maturation in Ichthyotic Epidermis. L. A. Goldsmith and H. P. Baden, Boston, Mass. AFCR

3. Changes in the Proportion of the Two Types of Human Dermal Collagen with Aging. E. Epstern, JR.* Bethesda, Md. (introduced by V. T. Devita). AFCR

4. In Vivo Effect of Ultraviolet Radiation on Mammalian Skin DNA. M. A. PathaK,** D. M. KRAMER,* and A. Kornhauser,* Boston, Mass. AFCR 
5. Metabolism of Testosterone by Hamster Skin and Flank Organ. E. C. Gomez* and P. Frost, Miami, Fla. AFCR

6. Biosynthetic Changes in the Cell Cycle of Mammalian Epidermal Cells. C. J. McDonald and L. J. Los,* Providence, R. I. AFCR

7. Protection by Dithiothreitol (DTT) Against Porphyrin Photosensitization. L. Harber, B. Goldstein,* J. Hsu,* and H. Hsu,* New York. ASCI (143)

8. Pemphigus-Like Antibodies in Patients with Morbilliform Penicillin Eruptions. M. J. Fullner, K. FuKUyama, A. Moshell,* and M. V. Klaus,* New York. AFCR

9. A Human Model to Study Cutaneous Necrotizing Angiitis Using Intradermal Epinephrine. A. L. Schroeter* and R. K. Winkelmann, Rochester, Minn. AFCR

10. Immunofluorescent Antibodies to Bovine Keratohyalin. S. Guss,* W. Idler,* M. Lutzner,** and A. Ugel,* Bethesda, Md. AFCR

11. Phagocytic Capability of Langerhans' Cell Granule. $\mathrm{K}$. Hashimoto, Memphis, Tenn. AFCR

\section{ENDOCRINOLOGY}

\section{2:00 p.m., Pennsylvania Room II, Haddon Hall \\ Co-Chairmen: Dr. Leonard Garren \\ Dr. Gerald Aurbach}

1. Reduction of Thyroid Hormone Release by Lithium in Thyrotoxicosis. R. Temple,* M. Berman,* and J. WolfF, Bethesda, Md. ASCI (305)

2. Lack of Thyroid Peroxidase Activity: a Cause of Congenital Goitrous Hypothyroidism. L. Valenta,* H. H. Bode,* A. L. Vickery,* and F. Maloof, ${ }^{* *}$ Boston, Mass. ASCI (316)

3. Characterization of the Hormonal Response to Luteinizing Hormone-Releasing Hormone ( $\mathrm{LH}-\mathrm{RH})$ in Prepubertal and Adult Subjects. A. J. Kastin,* A. V. Schally,* D. S. Schalch, * S. G. Korenman, C. Gual, ${ }^{*}$ and E. P. Pasten,* New Orleans, La., Rochester, N. Y., Iowa City, Iowa, and Mexico, D. F. ASCI (175)

4. Physiologic Investigation of the Posterior Pituitary Binding Proteins Neurophysin I and II. A. G. RoBINson, E. A. Zimmerman,* and A. G. Frantz, New York. AFCR

5. Luteinizing Hormone Releasing Factor (LRF) in Peripheral Blood of Normal Women. J. M. Malacara,* L. E. Seyler, JR.,* and S. Reichlin,** Farmington, Conn., and Newington, Conn. AFCR

6. Gonadotropin Binding by Rat Testis Receptors. K. J. Catt,* M. L. Dufau,* and T. Tsuruhara,* Bethesda, Md. (introduced by M. B. Lipsett**). ASCI (57)

7. Importance of Nuclear Androgen Retention for Hormone Action. L. P. Bullock,* R. J. Sherins,* and C. Wayne Bardin,* Hershey, Pa., and Bethesda, Md. (introduced by G. H. Jeffries). ASCI (50)
8. A Radioimmunoassay for Human Prolactin. H. Guyda,* P. Hwang,* and H. Friesen,* Montreal, Canada (introduced by J. M. McKenzie). ASCI (136)

9. Measurement of Prolactin Activity in Human Plasma by New Biological and Radioreceptor Assays. R. W. Turkington, Durham, N. C. ASCI (314)

10. Serum Triiodothyronine in Man, Measurements by Radioimmunoassay and Gas Chromatography. T. Mirsuma,* N. Nihei,* M. C. Gershengorn,* and C. S. HolLANDER, New York. AFCR

11. Triiodothyronine Radioimmunoassay. J. M. LIEBLICH* and R. D. Utiger, Philadelphia, Pa. ASCI (199)

\section{GASTROENTEROLOGY}

\author{
2:00 p.m., Windsor Room, Haddon Hall \\ Co-Chairmen: Dr. John Dietschy \\ Dr. Irwin Arias
}

1. The Effect of Phenobarbital on Bile Salt Metabolism and Cholesterol Secretion in the Primate. R. N. REDINGER* and D. M. Small, Boston, Mass. ASCI (255)

2. Mechanism of Type I Hypercoproporphyrinuria in Liver Disease. N. Kaplowitz,* N. Javitt, and A. Kappas, New York. ASCI (173)

3. Mechanism of Plasma Bilirubin (BILI) Rise During Fasting. J. R. Bloomer, P. Barrett, and N. I. Berlin,** Bethesda, Md., and Los Angeles, Calif. AFCR

4. Regulation of Portal Pressure in Cirrhosis. D. S. ZIMMON and R. E. Kessler,* New York. AFCR

5. False Neurochemical Transmitters in Hepatic Failure. J. E. Fischer* and J. H. James,* Boston, Mass. (introduced by W. G. Austen). ASCI (101)

6. Phenobarbital (PB) Enhances the Intestinal Transport of $\mathrm{Fe}^{50} \mathrm{SO}_{4}$ and Hemoglobin-Fe $e^{50}\left(\mathrm{Hgb}-\mathrm{Fe}^{50}\right)$. F. B. Thomas* and N. J. Greenberger, Columbus, Ohio. AFCR

7. Effects of Ethanol (ETOH) on Intestinal Metabolism of Endogenous Lipids. S. P. Mistilis* and R. K. OCKNER, San Francisco, Calif. AFCR

8. The Role of Bile Acid Micelles in Absorption of Fatty Acids Across the Intestinal Brush Border. V. L. SAlleE* and J. M. Dietschy, Dallas, Tex. ASCI (269)

9. Meals and the Enterohepatic Circulation (EHC) of Bile Salts Affect Bile Lithogenicity. R. D. SolowAY* and L. J. Schoenfield, Rochester, Minn. AFCR

10. Electrical Potential Profile of Rabbit Ileum: Effects of Theophylline and Cholera Exotoxin. N. HirschHORN* and H. S. Frazier, Boston, Mass. ASCI (151)

11. The Mechanism of Intestinal Uptake and Transcellular Transport of IgG in the Neonatal Rat. E. A. Jones* and T. A. Waldmann, Bethesda, Md. ASCI (167) 


\section{GENETICS}

\section{2:00 p.m., Garden Room, Haddon Hall \\ Co-Chairmen: Dr. Kurt Hirschhorn \\ Dr. Charles Epstein}

1. Autosomal Recessive Inheritance of Type A Renal Glycosuria. L. J. Elsas, D. Busse,* and L. E. RosenberG, New Haven, Conn., and Atlanta, Ga. AFCR

2. Globin Synthesis in Doubly Heterozygous (HETERO) $\alpha-\beta$ Thalassemia (THAL). Y. W. KAN,* N. GRANville,* and D. G. Nathan, Hartford, Conn. AFCR

3. Hepatic Fructose-1,6-Diphosphatase Deficiency: A Cause of Lactic Acidosis and Hypoglycemia in Infancy. A. S. Pagliara, I. E. Karl,* J. Keating,* B. Brown,"* and D. M. KIPNIs,** St. Louis, Mo. AFCR

4. Dyskeratosis Congenita with Fanconi-Type Anemia and Immunologic Defects: Chromosomal, Histologic, Hematologic, Skeletal and Immunologic Investigations. R. B. Scoggins, K. J. Prescott,* G. H. Asher,* W. K. BlayLOCK, and R. W. BRIGHT,* Richmond, Va. AFCR

5. Thalassemia with a High Oxygen Affinity Hemoglobin. M. Steiner, Providence, R. I. AFCR

6. Rescue of Senescent Human Fibroblasts by Hybridization with Cultured Hamster Cells. S. Goldstein* and C. LiN,* Hamilton, Canada (introduced by J. W. Littlefield). ASCI (124)

7. Genetic Regulation of Enzyme Induction in Somatic Cell Heterokaryons. T. D. GeLEHRTER* and E. B. Thompson,* New Haven, Conn., and Bethesda, Md. (introduced by L. E. Rosenberg). ASCI (115)

8. Metabolism of Isotopically Labeled Sulfur Amino Acids in a Patient Excreting $\beta$-Mercaptolactate-Cysteine Disulfide. J. C. Crawhall, P. Purkiss,* and J. B. StanBURY,** Montreal, Canada, and Boston, Mass. ASCI (70)

9. Differential Sensitivity of Epithelial and Fibroblast Cell Types to Virus-Induced Chromosome Breaks. W. W. Nichols, A. Levan,* L. KJellen,** and S. Sheldon,* Camden, N. J. ASCI (234)

10. Mild Homozygous $\beta$ Thalassemia in Negroes. A. BraverMAN,* P. R. McCURDY,** and O. MANOS,* Washington, D. C. AFCR

11. Familial Basal Ganglia Calcification: A Metabolic and Genetic Study. M. A. Moskowitz* and R. N. WinicKoFf,* New Haven, Conn., and Bethesda, Md. (introduced by G. F. Thornton). AFCR

\section{HEMATOLOGY}

\section{2:00 p.m., Vernon Room, Haddon Hall \\ Co-Chairmen: Dr. Charles Mengel \\ Dr. Ernest Beutler}

1. Granulocyte Colony Stimulating Factor: Relationship to Granulocytopenia. R. K. Shadduck and N. G. NAGABhushanam,* Pittsburgh, Pa. AFCR
2. Studies of Plasma Thrombopoietin in Man. L. W. Sullivan,* W. H. Adams,* and Y. K. Liu,* Boston, Mass. (introduced by C. P. Emerson**). ASCI (300)

3. The Erythropoietic Effect of Cyclic AMP in the Polycythemic Mouse. S. S. BotTomley, M. Z. Moore, ${ }^{*}$ and W. H. Whiтсомв,** Oklahoma City, Okla. AFCR

4. A New Hormone, "Coagulopoietin-K." M. H. KarpatKIN* and S. KarPatKIN, New York. ASCI (174)

5. Fate of Stress Reticulocytes: Hemolysis or Fragmentation? S. E. Come,* S. B. Shohet,* and S. H. Robinson, Boston, Mass. ASCI (68)

6. Glucose-Phosphate Isomerase (GPI) Deficiency Associated with Abnormal Osmotic Fragility and Spherocytes. F. Oski and E. Fuller, ${ }^{*}$ Philadelphia, Pa., and Louisville, Ken. AFCR

7. Participation of the Sixth Component of Complement in Normal Blood Coagulation and in the Acceleration of Coagulation Produced by Aggregated Gamma Globulin. T. S. Zimmerman,* C. M. Arroyave,* and H. J. Müller-Eberhard, La Jolla, Calif. ASCI (344)

8. Intermittent Acute Porphyria (IAP): New Evidence for a Basic Defect in Uroporphyrinogen Synthetase (URO-S). L. J. Strand,* B. F. Felsher,* A. G. Redeker, ${ }^{* *}$ and H. S. Marver, Dallas, Tex., and Los Angeles, Calif. ASCI (299)

9. Hereditary Leukemoid Reaction. L. G. SMIтH* and W. B. HerRING,** Chapel Hill, N. C., and Greensboro, N. C. AFCR

10. Bleeding Disorder Due to an Acquired Inhibitor of Fibrin Cross-Linking with Normal Factor XIII Concentration. R. D. Rosenberg,* L. LoRAnd,* B. Robertson,* and R. W. Colman, Boston, Mass., and Evanston, IIl. AFCR

11. Chronic Anemia and Wound Healing. M. JACOBSON,* S. Y. RheE,* S. K. Jegathesen,* R. Fresco,* and M. P. Westerman,** Chicago, Ill. AFCR

\section{IMMUNOLOGY AND CONNECTIVE TISSUE}

\author{
2:00 p.m., Rutland Room, Haddon Hall \\ Co-Chairmen: Dr. Hans Müller-Eberhard \\ Dr. Jonathan Uhr
}

1. Molecular Intervention in Genetically Determined Cellular Immune Deficiency Disorders. A. S. Levin,* L. E. Spitler,* D. P. Stites,* and H. H. Fudenberg, San Francisco, Calif. ASCI (196)

2. Transformation of a Histocompatibility Immunogen into a Tolerogen. S. Nimelstein, A. Hotti, ${ }^{*}$ and H. HolMAN,** Stanford, Calif. AFCR

3. Immunoglobulin on the Surface of Human Lymphocytes: Distribution on Lymphocytes from Normal, Hypogammaglobulinemic, and Chronic Lymphatic Leukemic Individuals. H. M. Grey,* E. Rabellino,* B. Pirofsky,* and E. Unanue,* Denver, Colo., Portland, Ore., and Boston, Mass. (introduced by R. S. Farr**). ASCI (132) 
4. Human Lymphocyte Transformation Induced by Autologous Lymphoblasts. M. E. WeKSLER* and G. BIRNBAUm,* New York (introduced by H. O. Heineman**). ASCI (325)

5. Specific Removal of Antibody and Antigen In Vivo. J-C. Bystryn,* I. Schenkein,* and J. W. Uhr, New York. ASCI (54)

6. Immune Function in $\mathrm{C}_{4}$ Deficient Guinea Pigs: Demonstration of an Alternate Pathway for Activation of the Complement Sequence. L. Ellman,* I. Green,* and M. M. FranK,* Bethesda, Md. (introduced by W. E. Paul). AFCR

7. Direct Lysis of Lymphocytes in Systemic Lupus Erythematosus on Exposure to Complement. P. Stastny* and M. ZIFF,** Dallas, Tex. ASCI (291)

8. Increased Incidence of Two Leukocyte Antigen Specificities in Systemic Lupus Erythematosus (SLE). F. Carl Grumet,* A. Couke,* J. G. Bodmer,* W. F. Bodmer,* and H. O. McDevitT, Stanford, Calif. ASCI (134)

9. Quantitative Allotype Deficiencies in Families of $\mathrm{Pa}$ tients with Primary Hypogammaglobulinemia. S. D. Litwin,* H. H. Fudenberg, and R. Kamin,* New York and San Francisco, Calif. (introduced by $\mathrm{H}$. Cleve). ASCI (201)

10. Serum-Binding of Morphine in Heroin Addicts. J. J. Ryan,* C. W. Parker, ${ }^{* *}$ and R. C. Williams, JR., ${ }^{* *}$ Albuquerque, N. M., and St. Louis, Mo. AFCR

11. Effect of Cyclic AMP and Colchicine on Hydrolase Release from Phagocytes. R. B. Zurier, P. Dukor,* and G. Weissmann, New York. AFCR

\section{INFECTIOUS DISEASES}

\section{2:00 p.m., Viking Room, Haddon Hall \\ Co-Chairmen: Dr. Purnell Choppin \\ Dr. Stephen Morse}

1. Alpha-Adrenergic Receptor Mediated Inhibition of Insulin Secretion During E. Coli Septicemia in the Subhuman Primate. P. E. Cryer, C. M. Herman,* and J. Sode,** Bethesda, Md. AFCR

2. Experimental Diarrhea Caused by Escherichia Coli. $\mathrm{H}$. L. Dupont, R. B. Hornick,** M. J. Snyder,* J. P. Libonati,* and S. B. Formal,* Baltimore, Md., and Washington, D. C. AFCR

3. Cholera Toxin Stimulation of Rat Lipocyte Adenyl Cyclase Activity. G. T. Curlin* and L. C. Chen,* Dacca, East Pakistan, and Baltimore, Md. (introduced by C. C. J. Carpenter). AFCR

4. ICU Epidemiology of Klebsiella Colonization. W. G. Johanson, JR., A. K. Pierce, and J. P. SAnford,** Dallas, Tex. AFCR
5. Isolated Neutrophil Dysfunction in Adults: a New Entity. J. S. Tan,* J. J. Akabutu,* A. M. Mauer, and J. P. PhaIr,* Cincinnati, Ohio (introduced by V. Donaldson**). ASCI (301)

6. Reduced Pyridine Nucleotide (RPN) Content in G6PDDeficient Granulocytes (PMN): an Explanation for Their Defective Bactericidal Function. R. L. BAEH NER,* R. B. Johnston, Jr.,* and D. G. Nathan, Boston, Mass. ASCI (13)

7. Polymorphonuclear Leukocytes and Serum Factors in Human Immunity to Pseudomonas aeruginosa. L. S. Young* and D. Armstrong,* New York (introduced by D. B. Louria). ASCI (338)

8. Endotoxin Stimulation of Thromboplastic Activity Generated by Leukocytes. R. LeRner, R. Goldstein,** and G. Cummings,* New York. AFCR

9. Cell-Mediated Immunity in Influenza. T. R. CAte, Durham, N. C. AFCR

10. Antibody to Specific and Cross-Reacting Antigens in Gram-Negative Bacteremia. B. E. KREGER, ${ }^{*}$ S. T. DontA,* and W. R. MCCABE, Boston, Mass. ASCI (189)

11. Infectious Mononucleosis: Appearance of Epstein-Barr Virus Neutralizing Activity during the Course of Disease. G. Miller* and J. C. Niederman,* New Haven, Conn. (introduced by D. M. Horstmann**). ASCI (220)

\section{METABOLISM}

\section{2:00 p.m., Pennsylvania Room I, Haddon Hall \\ Co-Chairmen: Dr. James Field \\ Dr. Edwin Bierman}

1. The Measurement of Hepatic Synthesis of Bilirubin and Its Delivery to Plasma in Man. E. A. Jones,* J. R. Bloomer,* P. D. Berk,* and N. I. Berlin,** Bethesda, Md. ASCI (168)

2. Turnover and Transport of Vitamin $D$ in Human Plasma. J. E. Smith* and D. S. Goodman, New York. ASCI (288)

3. Effect of Vitamin D Deficiency on the Bone Mineralization Rate. D. Baylink and J. Wergedal,* Seattle, Wash. AFCR

4. Human Plasma Very Low Density Lipoprotein (VLDL) Metabolism. D. Bilheimer,* S. Eisenberg,* and R. I. Levy, Bethesda, Md. ASCI (26)

5. Impaired Removal of Very Low Density Lipoprotein (VLDL) "Remnants" in the Pathogenesis of Broad- $\beta$ Disease (Type III Hyperlipoproteinemia). W. R. HAzzARD and E. L. BIERman, Seattle, Wash. AFCR

6. Variant Postheparin Lipolytic Activity (PHLA) in Familial Exogenous Hypertriglyceridemia (FEH). P. H. Schreibman,* D. L. Arons,* and R. A. Arky, Boston, Mass. ASCI (276) 
7. Regulation of Cholesterol Storage in White Adipose Tissue. A. Angel* and J. Farkas,* Toronto, Canada (introduced by C. H. Hollenberg). ASCI (8)

8. Effect of Induced Glucose Intolerance on the Fetal Insulin-Releasing Mechanism. D. H. Mintz,* R. A. Chez,* and D. L. Hutchinson,* Miami, Fla., and Pittsburgh, $\mathrm{Pa}$. (introduced by S. Papper**). ASCI (221)

9. Hypoalaninemia: the Cause of Ketotic Hypoglycemia of Childhood. A. Pagliara,* I. Karl,* D. Devivo,* R. FEIGIN,* and D. KIPNis, St. Louis, Mo. ASCI (244).

10. Secreted Molecular Species of Human Parathyroid Hormone (hPTH): Purification, Immunologic and Chemical Characterization. G. W. Sizemore,* S. B. Oldham,* J. A. Fischer,* and C. D. Arnaud,* Rochester, Minn. (introduced by A. Albert**). ASCI (285)

11. The Effect of Calcium Absorption upon Release of Gut Glucagon-Like Immunoreactivity (GLI): Evidence for Intestinal Influence upon Calcium Homeostasis. I. Böttger,* G. R. FAloona,* and R. H. Unger,** Dallas, Tex. ASCI (30)

\section{NEOPLASIA}

\section{2:00 p.m., Seaside Motel}

\section{Co-Chairmen: Dr. Elliott Osserman Dr. Phil Gold}

1. Skin Reactivity in Cancer Patients: Impaired Delayed Hypersensitivity (DH) or Faulty Inflammatory Response? M. W. Johnson,* H. I. MaIbach, and S. E. Salmon, San Francisco, Calif. AFCR

2. Two Liver Biopsies and Cytological Study of the Aspirates in the Diagnosis of Cancer Involving the Liver. E. Grossman,* M. J. Goldstein,* L. Koss,* S. J. Winawer, and P. Sherlock,** New York. AFCR

3. In Vitro Leukocyte Interferon Production as a Test of Immune Function in Patients with Hodgkin's Disease. A. L. R. Pidot* and O. R. McIntyre, Hanover, N. H. AFCR

4. Tumor Resistance Conferred by Intracellular Protozoa. J. B. Hibbs, JR.,* L. H. Lambert, JR.,* and J. S. RemIngton, Palo Alto, Calif. ASCI (149)

5. Blastic Transformation of Host Lymphocytes Cultured with Enzyme-Treated Cancer Cells. E. Watkins, Jr.,** L. L. Anderson, and Y. Ogata, Boston, Mass. AFCR

6. The Effect of Cyclic AMP on Syngeneic Tumor Immunity. P. G. RIGBY, Omaha, Nebr. AFCR

7. Growth and Morphology of Transformed Fibroblasts Are Regulated by Cyclic AMP and Prostaglandins. G. S. Johnson,* C. V. Peery,* J. Otten,* W. D. Morgan,* and I. Pastan, Bethesda, Md. ASCI (166)

8. Correlation Between Ultraviolet (UV)-Induced DNA Repair in Xeroderma Pigmentosum Skin Fibroblasts and Peripheral Blood Lymphocytes. P. G. BuRK,* S. H. Yuspa,* M. A. Lutzner, and J. H. Robbins, Bethesda, Md. AFCR
9. Dose Dependent Vincristine Effects. N. B. McWILLIAMs,* A. M. Mauer, ${ }^{* *}$ and B. C. Lampkin, Cincinnati, Ohio. AFCR

10. Discordant Secretion of Placental Alkaline Phosphatase (PAP), Chorionic Gonadotropin (HCG) and Somatomammotropin (HCS) in Patients with Cancer. H. Sussman, S. W. Rosen,** and B. D. Weintraub, Palo Alto, Calif., and Bethesda, Md. AFCR

11. "Calcitoxin": Evidence for the Secretion of a Hypercalcemia Producing Agent by Neoplastic Tissue. B. F. Rice and R. L. Ponthier, JR., * New Orleans, La. AFCR

\section{PULMONARY}

\section{2:00 p.m., Music Room, Chalfonte}

Co-Chairmen: Dr. Jay Nadel

Dr. Arend Bouhuys

1. Observations on Monocytes, Pulmonary Macrophages, and Large Alveolar Cells. A. H. Niden, * Philadelphia, $\mathrm{Pa}$. (introduced by S. Sherry**). ASCI (235)

2. Abnormal Deposition and Clearance of Inhaled Particles during Upper Respiratory Viral Infections. R. V. Lourenço,* E. D. Stanley,* B. Gatmaitan,* and G. C. JACKSON,** Chicago, Ill. ASCI (206)

3. The Duration of Ultrastructural Changes in Human Alveolar Macrophages After Cessation of Cigarette Smoking. P. E. G. MANN* and T. N. FinleY,** San Francisco, Calif. AFCR

4. Mucociliary Clearance in Denervated Bronchi. J. S. Brody, J. A. Waldhausen, ${ }^{* *}$ and D. E. Kuhl,* Philadelphia, Pa. AFCR

5. Physiologic Characterization of Papain Emphysema in the Rat. W. G. Johanson, JR., A. K. Pierce, and R. L. JoHnson, JR., Dallas, Tex. AFCR

6. Modification of Papain-Induced Emphysema by Progesterone and Stilbesterol. J. LIeberman,* Duarte, Calif. (introduced by D. Comings). ASCI (198)

7. Biosynthesis of Pulmonary Surfactant. R. PAwlowsKI, M. F. Frosolono, B. Charms, ${ }^{* *}$ M. Abrams, and C. CorbusIER,* Cleveland, Ohio. AFCR

8. Effect of Bilateral Carotid Body Resection on Ventilatory Control During Rest and Exercise in Man. R. Lugliani,* B. Whipp,* and K. Wasserman,** Torrance, Calif., and Los Angeles, Calif. AFCR

9. Respiratory Response to Hypoxia and $\mathrm{CO}_{2}$ in Awake and Anesthetized Dogs. L. W. Raymond, R. B. Weiskopf,* F. J. Wright,* R. S. Kronenberg,* W. Noble,* and J. W. Severinghaus,** San Francisco, Calif. AFCR

10. Pharmacological Modification of Histamine-Mediated Airway Responses. A. Bounuys, J. S. Douglas, ${ }^{*}$ and A. R. Guyatr,* New Haven, Conn. ASCI (31)

11. Frequency Dependence of Intrapulmonary Distribution of ${ }^{139}$ Xe. R. R. Martin* and N. R. Anthonisen,* Montreal, Canada (introduced by D. V. Bates**). ASCI (215) 


\author{
RENAL AND ELECTROLYTES \\ 2:00 p.m., Carolina Room, Chalfonte \\ Co-Chairmen: Dr. Roy Maffly \\ Dr. Floyd Rector
}

1. Role of Bence Jones and Other Urinary Proteins in Renal Dysfunction. H. Preuss,* F. Weiss,* R. IAmmaRino,* W. Hamack, and H. V. Murdaugh, Pittsburgh, Pa. ASCI (248)

2. An Alternative to the Pore Enlargement Hypothesis for Vasopressin Action. R. M. HAYs, N. FRANKI,* and R. Soberman,* New York. ASCI (146)

3. Effect of Peritubular Oncotic Pressure on Reabsorption of Sodium and Water in Isolated Perfused Proximal Tubule. M. ImaI* and J. P. Koкко,* Dallas, Tex. (introduced by D. W. Seldin**). ASCI (156)

4. Studies on the Mechanism of Rhabdomyolysis in Potassium Depletion. J. P. KNochel* and E. M. Schlein,* Dallas, Tex. (introduced by F. Rector, Jr.) ASCI (184)

5. Relationship Between Intrarenal Control of Sodium Reabsorption and Renin Secretory Activity (RSA). M. H.

Humphreys,* I. A. Reid,* R. C. Ufferman,* and L. E. EARLey, San Francisco, Calif. ASCI (155)

6. Mechanism of Inhibition of Proximal Sodium Reabsorption in Volume-Expanded Rats. T. M. Daugharty,* I. Ueki,* D. Nicholas,* and B. M. Brenner,* San Francisco, Calif. (introduced by T. B. Bradley, Jr.). ASCI (79)

7. Effect of Elevated Intratubular Pressure (ITP) on Renal Tubular Permeability. W. B. Lorentz, JR.,* W. E. LAssiter, and C. W. Gottschalk,** Chapel Hill, N. C. ASCI (205)

8. The Effect of Peritubular Capillary Flow Rate and Pressure on Glomerulotubular Balance. T. WADA,* H. S. Aynedjian,* and N. Bank, New York. ASCI (319)

9. Renal Tubular Basement Membrane: Effect of Albumin on Transmembrane Water Flow. L. W. Welling* and J. J. Grantham, Kansas City, Kans. AFCR

10. Effect of Carbonic Anhydrase Inhibition (CAI) by Benzolamide (CL-11,366) on $\mathrm{NaCl}$ and $\mathrm{NaHCO}_{3}$ Reabsorption in Rat Proximal Tubule. R. Kunau,* Minneapolis, Minn. (introduced by L. Tobian**). AFCR

11. The Different Effects of Osmotic Agents on $\mathrm{HCO}_{3}$ Handling by the Dog Kidney. W. N. Sukr, C. S. Hebert,* B. J. Stinebaugh, S. Bartow,* M. MartinezMaldonado, and G. Eknoyan, Houston, Tex. AFCR 


\title{
American Federation For Clinical Research, Inc.
}

\author{
28 TH ANNUAL MEETING \\ SUNDAY MORNING, MAY 2 \\ GENERAL MEETING \\ 8:30 a.m., Pennsylvania Room, Haddon Hall, Dr. John Oates, Presiding \\ BUSINESS SESSION \\ SCIENTIFIC SESSION \\ INTERMISSION \\ SCIENTIFIC SESSION \\ (concluded)
}

(The presentation of each paper will be limited to $12 \mathrm{~min}$.)

1. Cyclic 3'5'-Adenosine Monophosphate and Modulation of the Immunologic Release of Histamine and Slow Reacting Substance of Anaphylaxis in Human Lung. M. A. Kaliner,* P. J. LaRaia, R. P. Orange,* W. G. Austen,* and K. F. Austen,** Boston, Mass.

2. Detection of Splenic Anti-Platelet Antibody Synthesis in (Idiopathic) Autoimmune Thrombocytopenic Purpura. S. Karpatkin, N. Strick,* and G. W. Siskind,* New York.

3. Gluten Sensitive Enteropathy: Intestinal Synthesis of Antigluten Antibody In Vitro. A. M. FalchuK,* L. LAster, ** and W. STrober, Bethesda, Md.

4. Intermittent Acute Porphyria: Clinical Demonstration of a Genetic Defect in Porphobilinogen Metabolism. U. A. Meyer and H. S. Marver, Dallas, Tex., and San Francisco, Calif.

PRESIDENTIAL ADDRESS
5. The In Utero Diagnosis and Fetal Pathology of Niemann-Pick Disease (Sphingomyelinase Deficiency). E. L. Schneider,* R. O. Brady,* W. G. Ellis,* J. R. McCulloch,* and C. J. Epstein, San Francisco, Calif., and Bethesda, Md.

6. Quality of Patient Care As Seen by Multiphasic Screening. C. R. Kelly* and J. J. Manlin,* Indianapolis, Ind. (introduced by R. H. Murray**).

7. Response to Synthetic Thyrotropin Releasing Hormone in Man. E. D. Haigler,* J. M. Hershman, and J. A. Pittman, JR., ** Birmingham, Ala.

8. Induction of the Metabolism of Digitoxin in Man by Phenobarbital. H. Solomon, S. Reich,* Z. Gaut,** R. Pocelinko,* and W. Abrams,** Newark, N. J.

9. Coronary Steal : Regional Myocardial Blood Flow Studies During Isoproterenol Infusion in Acute and Healing Myocardial Infarction. G. V. R. K. Sharma,* R. KUMAR,* F. Molokhia,* and J. V. Messer, Boston, Mass.

10. Estradiol-Binding Macromolecules in Mammary Carcinoma. W. L. McGuire, J. Julian,* and G. C. ChamNESS,* San Antonio, Tex.

\section{AMERICAN FEDERATION FOR CLINICAL RESEARCH}

A N D

\author{
THE SOCIETY FOR PEDIATRIC RESEARCH
}

JOINT SPONSORSHIP OF TWO SYMPOSIA

\section{SYMPOSIUM I AMNIOCENTESIS IN THE PREVENTIVE CONTROL OF HEREDITARY DISEASES}

Saturday, May 1, 4:00 p.m., Pennsylvania Room I, Haddon Hall

Dr. J. Edwin Seegmiller, Presiding

1. Introduction: Present Status of Amniocentesis As a Diagnostic Procedure. Henry L. NadLer, Chicago, Ill.

2. Prenatal Detection of Cytogenetic Abnormalities. KURT HiRSCH HORN, New York.

3. Genetic Abnormalities Detectable by Biochemical Analysis. JoHn S. O’Brien, La Jolla, Calif.

\section{SYMPOSIUM II FACTORS IN CHILDHOOD \\ THAT INFLUENCE THE DEVELOPMENT OF ATHEROSCLEROSIS AND HYPERTENSION}

Saturday, May 1, 4:00 p.m., Traymore Room, Traymore Hotel

Dr. Donald S. Fredrickson, Presiding

1. Hyperlipoproteinemia in Children. Donald S. FredRICKson, Bethesda, Md.

2. Dietary Studies in Infants with Familial Type II Hyperlipoproteinemia. Charles J. Glueck, Cincinnati, Ohio.

3. Genetic and Environmental Interactions in Hypertension. LEwIS K. DAHL, Upton, N. Y.

4. Research in Infant Nutrition: the Untapped Well. Charles U. Lowe, Bethesda, Md. 


\title{
THE AMERICAN FEDERATION FOR CLINICAL RESEARCH S Y M P OS I UM

\author{
DRUG ABUSE
}

\author{
Saturday, May 1, 4:00 p.m., Pennsylvania Room II, Haddon Hall \\ Co-Chairmen: Dr. Daniel X. Freedman \\ Dr. Robert J. Levine \\ 1. Evolution of American Attitudes toward Narcotic Con- \\ trol. David F. Musto, New Haven, Conn. \\ 2. The Pharmacology of Drug Abuse in Man. Leo E. \\ Hollister, Palo Alto, Calif. \\ 3. The Specificity of Approach to Treatment of Narcotic \\ Addiction. Jerome H. Jaffe, Chicago, Ill. \\ 4. Panel Discussion. Drs. Freedman, Levine, Musto, \\ Hollister, and JafFe.
}

\section{SATURDAY EVENING, MAY 1 \\ SUBSPECIALTY MEETINGS}

(The presentation of each paper will be limited to $10 \mathrm{~min}$.)

\section{CARDIOVASCULAR I}

\section{8:00 p.m., Pennsylvania Room I, Haddon Hall \\ Dr. Francois M. Abboud, Presiding}

1. The Descending Limb of Left Ventricular Performance. D. C. MacGregor,* J. W. Covell, W. H. McCullagh,* and J. Ross, JR., San Diego, Calif.

2. Abnormal Peripheral Vascular Dynamics in Patients with Acute Myocardial Infarction: Diminished Reflex Arteriolar Constriction. J. L. Hughes, ${ }^{*}$ E. A. Amsterdam, D. T. Mason, E. Mansour,* and R. Zelis, Davis, Calif.

3. Alterations in the Baroreceptor Reflex in Conscious Dogs with Congestive Heart Failure. Charles B. Higgins,* Stephen F. Vatner, Dwain L. Exkberg,* Dean Franklin,* and Eugene Braunwald,** San Diego, Calif.

4. Impaired Reflex Vasoconstriction in Chronically $\mathrm{Hy}$ poxic Patients. D. D. Heistad, F. M. Abboud, A. L. MARK, and P. G. Schmid, Iowa City, Iowa.

5. Ethacrynic Acid Induced Alterations of Myocardial Contractility. A. H. L. From,* J. L. Probstrield,* D. G. Knight,* and T. R. Smith,* Minneapolis, Minn. (introduced by $R$. Bache).

6. Myosin Synthesis and Degradation during Development of Cardiac Hypertrophy. S. Kimata,* E. Morkin, and J. J. Skillman, Boston, Mass.

7. Adenyl Cyclase in Hamster Cardiomyopathy. PAUL J. LaRaia, Edward W. Gertz,* and Edmund H. SonnenBLICK, Boston, Mass.

8. Angiotensin's Inotropic and Mitochondrial Effects. ThEodore Goodfriend, David Allmann,* Kenneth Kent,* Peter Dempsey,* and Theodore Cooper, Madison, Wis., Indianapolis, Ind., and Bethesda, Md.

\section{CARDIOVASCULAR II}

8:00 p.m., Pennsylvania Room III, Haddon Hall

Dr. J. Thomas Bigger, Jr., Presiding

1. Regional Myocardial Blood Flow during Angina Pectoris and after Nitroglycerin. Attilio Maseri, Paolo Mancini,* Paolo Pisani,* Antonio L'Abbate,* Antonio Pesola,* Carlo Contini,* Glauco Magini,* and luigi Donato,* Pisa, Italy.

2. Regional Myocardial Blood Flow in Coronary Artery Disease. E. M. Dwyer, R. B. Dell, and P. J. Cannon, New York.

3. Serum Cortisol and Plasma Free Fatty Acids As Prognostic Indicators in Acute Myocardial Infarction. RAvI Prakash,* Matija Horvat,* James Forrester,* and William W. Parmley,** Los Angeles, Calif.

4. The Source of Serum Creatine-Phosphokinase After Experimental Myocardial Infarction. LouIs CoHEN,** CyNthia Jelinek,* Raul Falicov, and Leon Resnekov,** Chicago, Ill.

5. Myocardial Revascularization in the Acute Stage of Myocardial Infarction. Rimgaudas Nemickas,* Patrick Scanlon, Rogue Pifarre, and John R. Tobin, JR.,* Maywood, Ill.

6. Mechanical Benefits and Hazards of Isoproterenol during Myocardial Hypoxia. O. H. L. BING, W. W. Brooks,* and J. V. Messer, Boston, Mass.

7. Depressed Cardiac Muscle and Mitochondrial Function in Potassium Depletion. C. E. Harrison and H. N. Coleman, Rochester, Minn.

8. Instantaneous Force-Velocity Relationships in the Intact Heart. William Grossman, Harold Brooks, Steven Meister, Herbert Sherman, and Lewis Dexter, Boston, Mass. 


\section{CLINICAL PHARMACOLOGY}

8:00 p.m., Rutland Room, Haddon Hall

Dr. Kenneth L. Melmon, Presiding

1. Serial Serum Digitalis Levels in Patients with Acute Myocardial Infarction. JoHN MORRISON* and ThOMAS Killip,** New York.

2. Measurement of Plasma and Urine Ouabain Concentrations by Radioimmunoassay: Pharmacokinetic Studies. T. W. Smith, R. Selden,* and W. Findley,* Boston, Mass.

3. Effect of Route of Administration on the Potency and Time-Course of Action of Propranolol. C. R. CleaveLAND* and D. G. Shand, Nashville, Tenn.

4. Clinical and Metabolic Effects of L- $\alpha$-Methyldopa Hydrazine (MK-486) in Parkinson's Disease. T. H. Hsu,* J. R. Bianchine, and F. S. Messina,* Baltimore, Md.

5. Effects of Phenobarbital on Bile Salt Metabolism in Cholestasis. A. Stiehl,* M. M. Thaler,* and W. H. Admirand, San Francisco, Calif.

6. Effect of Glutethimide on the Plasma Concentration of Unconjugated Bilirubin. Paul D. Berk and Terrence Blaschke, Bethesda, Md.

7. Effect of Ethanol on Hepatic Rough and Smooth Endoplasmic Reticulum. H. IsHII,* J.-G. Joly, and C. S. Lieber, New York.

8. Effects of Prostaglandin $A_{1}$ on Left Ventricular Dynamics in Conscious Dogs. C. B. Higgins,* S. F. VAtNER, D. Franklin,* and E. Braunwald,** San Diego, Calif.

\section{ENDOCRINOLOGY}

\author{
8:00 p.m., Carolina Room, Chalfonte \\ Dr. Robert L. Ney, Presiding
}

1. Evidence That the "Renal Pressor Substance" of Grollman Is Related to Angiotensin I. J. R. SchweIKERT,* R. M. Carey,* and G. W. LiddeE,** Nashville, Tenn.

2. Rapid Effects of Estrogen on the Renin-Angiotensin System. J. Menard,* M. D. Cain,* and K. J. Catt, Bethesda, Md., and Melbourne, Australia (introduced by M. B. Lipsett**).

3. Site of Stimulation of Aldosterone Biosynthesis by Angiotensin and Potassium. R. D. Brown,* C. A. Strott, and G. W. Lidple,** Nashville, Tenn.

4. Calcitonin Metabolism: Plasma Disappearance Curves and the Significance of Protein Binding. J. F. HABENER, F. R. Singer, R. M. Neer, J. A. Parsons,* and J. T. PotTs, JR., Boston, Mass., and London, England.

5. Hyperparathyroidism Secondary to Long-Term Therapy of Paget's Disease of Bone with Calcitonin. W. J. DUBÉ, R. S. Goldsmith, S. B. Arnaud,* and C. D. Arnaud, Rochester, Minn.

6. The Value of Serum Ionized Calcium in the Diagnosis of Normocalcemic and Hypercalcemic Primary Hyper- parathyroidism. J. C. Low,* M. Schaff,** J. M. EARLL,** J. T. PIEchockI,* and T. K. LI,* Washington, D. C.

7. The Biosynthesis of Human Growth Hormone and Prolactin. P. Hwang, * H. Guyda,* and H. Friesen, Montreal, Canada.

8. Divergent Effects of Medroxyprogesterone Acetate on Growth Hormone and Prolactin in the MTW15 Tumor Bearing Rat. W. B. Malarkey* and W. H. DaughaDAY, ${ }^{* *}$ St. Louis, Mo.

\section{GASTROENTEROLOGY}

\author{
8:00 p.m., Vernon Room, Haddon Hall \\ Dr. James E. McGuigan, Presiding
}

1. Association of Consumption Coagulopathy with Bleeding in Cirrhosis. S. Mobarhan,* J. Gajewski,* N. Grace, M. GreenberG, F. Iber, and V. Gurewich,* Boston, Mass.

2. A Cerebrospinal Fluid Transfer Model for Hepatic and Uremic Encephalopathy. ROBERT W. BRENNAN and Fred Plum,** New York.

3. Glomerulonephritis with Deposition of Australia Antigen-Antibody Complexes in the Glomerular Basement Membrane. B. Combes,** P. Stastny, J. Shorey, E. Eigenbrodt,* A. Barrera,* A. Hull, and N. Carter,** Dallas, Tex.

4. Liver Injury and Immunologic Hyperactivity. MICHAEL Sorrell* and Carroll M. Leevy,** Newark, N. J.

5. Effects of Acute Biliary Tract Obstruction on Bile Salt and Cholesterol Metabolism. R. N. Redinger,* S. M. Strasberg,* and D. M. Small, Boston, Mass.

6. Bile Salts Producing Stress Ulcers During Shock. K. Hamza* and L. DenBesten,** Iowa City, Iowa.

7. Rapid Screening Method for Macroamylasemia. LouIS Fridhandler,* J. Edward Berk,** and Masatoshi UEdA,* Irvine, Calif.

8. Tryptophan-Induced Indoleaceticaciduria: a New Variant of the Carcinoid Syndrome. H. E. Williams, K. M. Wilson,* W. Trager,* and K. L. Melmon, San Francisco, Calif.

\section{HEALTH CARE}

\section{8:00 p.m., Pennsylvania Room II, Haddon Hall Dr. Donald C. Riedel, Presiding}

1. The Clinical Specialist in Gynecology As a Component of the Optimal Health Care System. David E. Copher,* Indianapolis, Ind. (introduced by D. R. Challoner).

2. Physician's Assistant in Peripheral Vascular Disease. R. Penneys** and K. D. Schiffelbian,* Philadelphia, $\mathrm{Pa}$.

3. Automated Histories in an Internist's Practice. $\mathrm{H}$. K. Thompson,* J. O. Smith,* W. E. Hammond, and E. H. Estes,* Durham, N. C. (introduced by Robert E. Whalen). 
4. The Yale Affiliated Gastroenterology Program. H. M. SpIro,* R. S. Rosson,* and A. G. Ferrari,* New Haven, Conn. (introduced by $\mathrm{H}$. Binder).

5. Longitudinal Effects on Cardiac Patients in an Experimental Health Facility. Genrose J. Alfano,* Harold Rifkin,** Herbert S. Levine,* and Martin GoldMAN,* Bronx, N. Y.

6. Patient Care Activities of Physicians. D. L. Rabin* and B. H. Starfield,* Baltimore, Md. (introduced by M. L. Peterson**).

7. Evaluation of the Initial Care of Hypertensive Patients. Marston Linehan,* Cameron Emmott,* James E. Hammarsten,* David Pollack,* A. William HorsLEY,** and Edward D. Frohlich, Oklahoma City, Okla.

8. Time-Oriented Patient Records and a Computer DataBank. James F. Fries, Stanford, Calif.

\section{HEMATOLOGY}

7:00 p.m., Windsor Room, Haddon Hall

Dr. James W. Hampton, Presiding

1. Effect of 2,3-Diphosphoglycerate on the Oxygenation of Mammalian Hemoglobins. H. F. Bunn, Boston, Mass.

2. Effect of Hemodialysis on $\mathrm{pH}$, Inorganic Phosphate and Red Cell 2,3-DPG in Patients with Uremia. P. C. Raich,* J. M. Rodriguez,* T. Desai,* D. R. Korst,** and N. T. Shahidi,* Madison, Wis.

3. Site of Action of a Serum Inhibitor of Erythropoiesis. Ralph Zalusky, Esmail. D. Zanjani,* and John Ross,* New York.

4. Differences in Hemoglobin Synthesis in Idiopathic Ineffective Erythropoiesis and Di Guglielmo's Disease. P. M. Eastman,* R. Schwartz,* and S. L. Schrier, Stanford, Calif.

5. Altered Phagocyte Function in the Myeloproliferative Disorders. M. R. Cooper,* L. R. DeChatelet,* C. E. McCall,* and C. L. SpUrR, Winston-Salem, N. C.

6. Electrostatic Bonds in Sickling Interactions. RoBert M. Bookchin* and Ronald L. Nagel,* Bronx, N. Y. (introduced by Ernst R. Jaffé**).

7. Erythropoietic Protoporphyria: a Mechanism of Erythrocyte Membrane Damage During Photohemolysis. B. D. Goldstein,* L. C. Harber, ** R. Cuzzi-Spada,* and M. R. Levine, New York (introduced by R. Silber).

8. Granulocytopenia Caused by Anticephalothin Antibodies. A. S. Levin,* R. S. Weiner,* H. H. FudenberG,** P. Spath,* and L. Petz.

\section{NATIONAL BLOOD CLUB}

\section{9:00 p.m., Windsor Room, Haddon Hall Immunologic Deficiency Diseases}

1. Basic Concepts of Immune Responsiveness. Fred S. Rosen, Boston, Mass.

2. The Immunologic Deficiency Diseases. Robert A. Good, Minneapolis, Minn.
3. Transfer Factor and Immunologic Reconstitution. $H$. Sherwood Lawrence, New York.

\section{INFECTIOUS DISEASES}

$$
\text { 8:00 p.m, Seaside Motel }
$$

Dr. Thomas C. Merigan, Presiding

1. Urinary Immunoglobulin and Antibody Activity. J. W. Smith, W. L. Hand, and J. P. Sanford, ** Dallas, Tex.

2. Glomerular Lesions Produced in Rabbits by Homologous Serum and Homologous IgG Treated with $\beta$-Hemolytic Streptococcus. Rawle M. McIntosh* and Donald B. Kaufman,* Los Angeles, Calif. (introduced by F. G. Smith, Jr.).

3. A Spectrum of Liver Pathology in Family Members with Hepatitis Associated Antigen. William BaNCroft,* Raphael Warkel,* Anthony Talbert,* and Philip Russell,* Washington, D. C. (introduced by Edward Buescher**).

4. Defective Bactericidal Functions of Chediak-Higashi Syndrome Leukocytes. Richard K. Root, Bethesda, Md.

5. Killing of Cryptococcus Neoformans by Human Leukocytes. Richard D. Diamond,* Richard K. Root, and John E. Bennett, Bethesda, Md.

6. The Function of the Fibrinolytic System in Patients with Gram-Negative Bacteremia. Terry Satterwhite,* Jacek Hawiger, Samuel Burklow,* and M. Glenn Koenig, Nashville, Tenn.

7. Surface Manifestations of Antibiotic-Induced Alterations in Protein Synthesis in Bacterial Cells. Albert S. Klainer and Robert L. Perkins, Columbus, Ohio.

8. Automated Radiometric Detection of Bacterial Growth in Human Infections. Harold J. DeBlanc, Jr.,* Frank H. DeLand,* and Henry N. Wagner, JR.,** Baltimore, Md.

\section{METABOLISM}

$$
\begin{gathered}
\text { 8:00 p.m., Music Room, Chalfonte } \\
\text { Dr. Jean D. Wilson, Presiding }
\end{gathered}
$$

1. Physicochemical Basis for the Formation of CalciumContaining Renal Stones. Charles Y. C. Pak, Hibbard E. Williams, and Belle Ruskin,* San Francisco, Calif., and Bethesda, Md.

2. Urinary Camp and Parathyroid Hormone in the Differential Diagnosis of Hypercalcemia. Peter H. Dohan,* Kamejiro Yamashita,* Reed Larsen, Bernard Davis, Leonard Deftos, and James B. Field, ${ }^{* *}$ Boston, Mass., and Pittsburgh, $\mathrm{Pa}$.

3. Prevention of Disuse Osteoporosis in the Rat. R. J. Cates,* D. D. Sheets,* and C. C. Johnston, JR., Indianapolis, Ind. 
4. Tolbutamide: An Inhibitor of Cyclic AMP Phosphodiesterase in Islet Cells and Other Tissues. IrA D. Goldfine, Jesse Roth, Robert L. Perlman, and Joseph MUenzer, Bethesda, Md.

5. Alanine-Glucagon Relationships in Control of Gluconeogenesis. W. Muller,* D. Rocha,* G. Faloona,* and R. Unger,** Dallas, Tex.

6. Secretin and Glucose: Stimulation of Rapid Insulin Response from Separate Functional Pools. R. L. LERNER* and D. Porte, JR., Seattle, Wash.

7. Inhibition of Hepatic Glucose Production: Primary Action of Small Increments in Endogenous Insulin Secretion in Man. Phillp Felig and John Wahren,* Stockholm, Sweden, and New Haven, Conn.

8. Abnormal Lipoprotein Electrophoretic Patterns Produced by ACTH Infusion. Robert L. KaufmanN,* ELliot J. Rayfield,* Leslie I. Rose, Robert G. Dluhy, Gordon H. Williams, and J. Stuart Soeldner, Boston, Mass.

\section{PULMONARY}

\section{8:00 p.m., Garden Room, Haddon Hall}

Dr. Ronald F. Coburn, Presiding

1. Isolated Maximum Mid-Expiratory Flow Rate Abnormalities-a Spirographic Manifestation of Small Airway Disease. E. R. McFadden, JR. and David A. Linden,* $\mathrm{El}$ Paso, Tex.

2. Early Effects of Asbestos Exposure on Lung Function. G. Jodorn,* G. W. GibBs,* P. T. Macklem,* J. C. McDonald,* and M. R. Becklake,* Montreal, Canada (introduced by G. A. Klassen).

3. Respiratory Effects of Prostaglandins $A_{1}, E_{1}$ and $F_{2}$. Takahito Hirose* and Sami I. SaId,** Richmond, Va.

4. Demonstration of Flow Limiting Segment in Excised Lungs. James Friend* and JoHn Butler,** Seattle, Wash.

5. Metabolic Control of Ventilation. Sanford Levine* and W. E. HuckabeE, ** Boston, Mass.

6. Brain and CSF Glutamic Acid and Glutamine Concentrations in Respiratory Acidosis and Alkalosis. N. S. Shore,* D. C. Shannon,* and H. Kazemi, Boston, Mass.

7. Response Rates of Ventilation and Cerebral Blood Flow to $\mathrm{CO}_{2}$ in Normal Goats and Abnormal Man. N. H. Edelman, P. G. Tuteur,* L. McHenry,* and N. S. Cherniack, Philadelphia, Pa.

8. Increased Pulmonary Diffusion Capacity With Elevated Cerebrospinal Fluid Pressure. Richard E. Brashear and Rodolfo L. Pamintuan, * Indianapolis, Ind.

\section{RENAL AND ELECTROLYTES I}

8:00 p.m., Viking Room, Haddon Hall

Dr. Thomas F. Ferris, Presiding

1. Effect of Cyclic AMP and Sympathomimetic Amines on Renin Secretion and Renal Hemodynamics. NAthaNIEI Winer and Walter Walkenhorst,* Kansas City, Mo.
2. $\mathrm{PGE}_{1}$ Stimulation of ${ }^{3} \mathrm{H}$-Thymidine Incorporation into Renal Slice DNA. M. V. RAGNi* and H. G. Preuss, Pittsburgh, $\mathrm{Pa}$. (introduced by $\mathrm{H}$. V. Murdaugh).

3. Dissociation of Increased Filtered Load from Compensatory Renal Growth in Ureteral Diversion. E. WeInman,* K. Renquist,* R. Stroup,* M. Kashgarian, and J. Hayslett, New Haven, Conn.

4. Evidence that $\mathrm{H}+$ Secretion Is Not a Major Determinant of the Absolute Net Reabsorptive Rate for Water of Rat Proximal Tubules. D. Z. Levine, L. Nash,* and J. Lemke,* Ottawa, Canada.

5. Resistance to Glucose Uptake in Uremia. R. Swenson,* D. Peterson,* M. Eshleman,* and G. Reaven,** Palo Alto, Calif.

6. Effects of Lithium on Vasopressin Responsiveness In Vivo and In Vitro. Donald Rotenberg,* Jules B. Puschett, P. Ramsey,* J. Stokes,* J. Mendels,* and Irwin Singer, Philadelphia, Pa.

7. The Phenylacetamides: Potent Enhancers of Vasopressin. E. S. Lozada,* J. Gouaux,* and R. M. Hays,** New York.

8. Micropuncture Study of Post-Obstructive Diuresis. W. E. Yarger,* H. S. Aynedjian,* and N. BAN K,** New York.

\section{RENAL AND ELECTROLYTES II}

$$
\begin{gathered}
\text { 8:00 p.m., West Room, Haddon Hall } \\
\text { Dr. James R. Clapp, Presiding }
\end{gathered}
$$

1. Reduction in Proximal Tubule Fluid Reabsorption After Clamping the Contralateral Kidney in the Dog. J. H. Dirks, N. L. M. Wong,* and R. L. Evanson,* Montreal, Canada.

2. Increased Passive $\mathrm{NaCl}$ Flux in Necturus Proximal Tubule During Volume Expansion. C. J. Bentzel* and K. R. Spring,* Buffalo, N. Y. (introduced by D. K. Hare).

3. Effects of Saline Infusion on Glomerulotubular Balance: Roles of Nephron Filtration Rate and Absolute Tubular Reabsorption. E. Bartoli and L. E. Earley, San Francisco, Calif.

4. Proximal Function in Volume Loading in the Rat. Morris Davidman,* R. C. Lalone,* E. A. Alexander, and N. G. Levinsky, Boston, Mass.

5. Continuous Pressure Measurements in Renal Tubules and Postglomerular Vessels Recorded Simultaneously Using Dual Servo Controlled Transducers. B. M. Brenner,* T. M. Daugharty, and J. L. Troy, San Francisco, Calif.

6. Glomerular Hydrostatic Pressure and Effective Filtration Pressure in the Dog During Hydropenia, Acute Volume Expansion and Aortic Constriction. A. H. Israelit,* F. C. Rector, JR., and D. W. Seldin,** Dallas, Tex.

7. Evidence for Functional Nephron Heterogeneity. JAY H. Stein, Rolando C. Congbalay,* Richard W. Osgood,* and Thomas F. Ferris, Columbus, Ohio.

8. Mechanisms of Intestinal Efflux During Extracellular Fluid Expansion. J. T. HIGGINS, JR., Indianapolis, Ind. 


\title{
THE AMERICAN FEDERATION FOR CLINICAL RESEARCH S Y M P OS I U M
}

\section{THE LARGE SCALE CLINICAL TRIAL: PRINCIPLES AND PROBLEMS}

\author{
Sunday, May 2, 8:00 p.m., Pennsylvania Room III, Haddon Hall \\ Chairman: Dr. Louis C. Lasagna \\ 1. The University Group Diabetes Program Study. Chris- \\ TIAN R. KLIMT, Baltimore, Md. \\ 2. Effects of Treatment on Morbidity in Hypertension-the \\ Veterans Administration Cooperative Study. Edward D. \\ FrIEs, Washington, D. C. \\ 3. General Considerations in Study Design. Louis Lasagna, \\ Rochester, N. Y.
}

\section{SUNDAY EVENING, MAY 2 \\ SUBSPECIALTY MEETINGS}

(The presentation of each paper will be limited to $10 \mathrm{~min}$. )

\section{CARDIOVASCULAR I}

8:00 p.m., Pennsylvania Room II, Haddon Hall

Dr. Francois M. Abboud, Presiding

1. Effect of Prostaglandins on Guinea Pig Myocardial Adenyl Cyclase. Irwin KleiN* and Gerald S. Levey, Miami, Fla.

2. Effect of Prostaglandin $A_{1}$ on Several Vascular Beds in Man. H. B. Barner, G. C. Kaiser, and J. B. Lee, St. Louis, Mo.

3. Effect of Cadmium Feeding on Heart Content of Norepinephrine in Rats. H. F. Delisle, * H. M. BRECht,* J. M. Rojo-Ortega,* A. Gattereau,* and J. Genest,** Montreal, Canada.

4. Three Cineangiographic Models for Measurement of Right Ventricular Stroke Volume. C. B. Mullins and R. S. KNAPP, II,* Dallas, Tex.

5. Right Ventricular Volumes in Atrial Level Shunts. RoBERT Rosenblum** and Lawrence Annes,* New York.

6. Lung and Plasma Converting Enzyme. Annette Fitz and Merrill Overturf,* Iowa City, Iowa.

\section{CARDIOVASCULAR II}

8:00 p.m., Pennsylvania Room I, Haddon Hall

Dr. J. Thomas Bigger, Jr., Presiding

1. Bilateral Bundle Branch Block As a Common Cause of Complete Heart Block. Tsung O. Cheng, ${ }^{* *}$ Washington, D. C.
2. Lown-Ganong-Levine Syndrome: Electrophysiologic Studies. William J. Mandel,* Ronald Danzig,* and H. Hayakawa, * Los Angeles, Calif. (introduced by John K. Vyden).

3. Sino-Atrial Entrance Block. Bruce N. Goldreyer and Anthony N. Damato, Staten Island, N. Y.

4. Arrhythmias Induced by Isometric (Handgrip) Exercise and Dynamic Exercise. J. M. Atkins,* O. A. MatTHews,* J. D. Houston,* G. BlomQvist, and C. B. MULLINS, Dallas Tex.

5. Ventricular Defibrillation Through a Single Intravascular Catheter Electrode System. M. Mirowski,** M. Mower,* William S. Staewen,* Rollin H. Denniston, Bernard Tabatznik,* and Albert I. Mendeloff,** Baltimore, Md.

6. Intracardiac Defibrillation. Bernard L. Charms,** Alan Miller,* and Arthur Kramer,* East Cleveland, Ohio.

\section{DERMATOLOGY}

\section{8:00 p.m., West Room, Haddon Hall \\ Dr. Sidney N. Klaus, Presiding}

1. Darier's Disease: an Electron Microscopic Study. S. K. Gottlieb* and Marvin A. Lutzner,** Bethesda, Md., and Boston, Mass.

2. A Genetic Diathesis to Skin Cancer. M. M. Lane Brown* and D. F. Melia,* Cambridge, Mass. (introduced by H. A. Haynes).

3. Collagenase and Epidermolysis Bullosa. G. S. Lazarus, Boston, Mass. 
4. Evidence for the Site of Action of Light on ${ }^{14} \mathrm{C}$-Acetate Incorporation into Human Skin Sterols. Homer S. Black,* J. D. Smith,* B. L. Held,* and E. B. Sмith, Houston, Tex.

5. Photosensitive Cheilitis. Robert Rich,* Charles KIrKpatrick, and Alan Rosenthal, Bethesda, Md.

6. Computer Assisted Dermatological Diagnosis. MichaEL Fisher,* Robert Fox,* and Aisik Newman,* Bronx, N. Y. (introduced by Ernst R. Jaffé).

\section{ENDOCRINOLOGY}

$$
\begin{gathered}
\text { 8:00 p.m., Carolina Room, Chalfonte } \\
\text { Dr. Robert L. Ney, Presiding }
\end{gathered}
$$

1. The Significance of Triiodothyronine in Maintenance of Euthyroid Status After Treatment of Hyperthyroidism. Kenneth Sterling,** Milton A. Brenner,* Edward S. Newman,* and Diego Bellabarba, New York.

2. A Simple Test for Selecting the Appropriate Thioamide Regimen in Thyrotoxicosis. H. V. BARNES* and T. BLEDSOE, Baltimore, Md.

3. Effects of Hyperthyroidism on Estradiol Metabolism and Functioning of the Leydig Cell-Pituitary Axis. $H$. Ruder,* P. Corvol,* J. Mahoudeau,* and M. Lipsett,** Bethesda, Md.

4. Synthetic Thyrotropin Releasing Hormone: a Specific and Potent Stimulator of Thyrotropin Release in Man. M. S. Anderson,* C. Y. Bowers, A. J. Kastin, D. S. Schalch, A. V. Schally,* R. D. Utiger, P. J. Snyder,* J. F. Wilber, and A. J. Wise,* Chicago, Ill., New Orleans, La., Rochester, N. Y., and Philadelphia, $\mathrm{Pa}$.

5. A New Technique for Labeling Gonadotropins and Physiological Studies. J. VaItukaitis,* J. Hammond,* R. Sherins, and G. T. Ross,* Bethesda, Md.

6. Insulin, Growth Hormone and Chorionic Somatomammotropin Secretion During Prolonged Fasting in Pregnancy. JoHn E. Tyson,* KarL Austin,* and Jon FARINHOLT,* Baltimore, Md. (introduced by Victor A. McKusick).

\section{GASTROENTEROLOGY}

\section{8:00 p.m., Windsor Room, Haddon Hall \\ Dr. James E. McGuigan, Presiding}

1. Pathophysiological Characteristics of E. coli Enterotoxin: a Comparison with Cholera Exotoxin. H. P. Sherr,* J. G. BANwell,* and T. R. Hendrix,** Baltimore, Md.

2. The Role of Micelle Uptake During Bile Acid and Fat Absorption by the Intestinal Mucosa. Frederick A. WiLson* and John M. Dietschy, Dallas, Tex.

3. The Intestinal Lesion in Folate Deficiency. J. Hermos,* W. Adams,* Y. Liu, L. Sullivan, and J. Trier, Boston, Mass.
4. Pathogenesis of Congenital Alkalosis with Diarrhea. F. A. Bieberdorf,* J. S. Fordtran,* P. Gorden, and H. Levitin, Dallas, Tex., Bethesda, Md., and New Haven, Conn.

5. Serotonin Inhibition of Gastrin Induced Gastric Acid Secretion. D. H. Winship and T. J. Shuck,* Columbia, Mo.

6. Carcinoembryonic Antigen in the Evaluation of Gastrointestinal Malignancy. T. MOORE,* H. KuPCHIK,* N. Marcon,* P. Dhar,* and N. Zamcheck,** Boston, Mass.

\section{HEMATOLOGY}

$$
\begin{gathered}
\text { 8:00 p.m., Vernon Room, Haddon Hall } \\
\text { Dr. James W. Hampton, Presiding }
\end{gathered}
$$

1. Heparinase as a Reagent to Clear Heparin from Plasma Samples. Henry S. Kingdon, Chicago, Ill.

2. Platelet and Fibrinogen Consumption with Surgery. S. J. Slichter,* J. L. Leandoer,* D. D. Funk,* and L. A. Harker, Seattle, Wash.

3. Molecular Structure of Plasma Transglutaminase: Enzyme for Fibrin Cross-Linkage. James W. Hampton, David Bannerjee,* Robert O. Morton,* Robert Delaney,* and Charles L. Cahill,* Oklahoma City, Okla.

4. A Radioimmunoassay Method for Serum Vitamin $B_{12}$ Using Antibody to Intrinsic Factor. Harvey I. Spector* and Richard K. Donabedian, New Haven, Conn.

5. Effect of Prior Transfusion on Marrow Grafting. $R$. Storb,* R. H. Rudolph,* T. C. Graham,* and E. D. Thomas, Seattle, Wash.

6. Quantitation of Marrow Granulocyte Precursors. JoHN Northup,* Joan Bull,* and Paul P. Carbone, Bethesda, Md.

\section{IMMUNOLOGY}

\author{
8:00 p.m., Viking Room, Haddon Hall \\ Dr. Fred S. Rosen, Presiding
}

1. Selective Effect of Thymectomy on Memory in a Genetically Controlled Immune Response. F. CarL Grumet,* Graham F. Mitchell, * and Hugh O. McDevitt, Stanford, Calif.

2. The Monocyte Receptor: Inhibition of Receptivity by Low Molecular Weight Peptides of the Fc Fragment. E. Gelfand,* N. Abramson, E. Merler,* and F. Rosen,* Boston, Mass.

3. Isolation of Antibody Reactive Mitogenic Receptors from Human Lymphoid Cell Membranes. A. B. Einstein, JR., D. L. MANN, S. Ficker,* and W. D. Terry, Bethesda, Md.

4. Characterization and Localization of Immunoglobulins on Human Lymphocytes. S. Berney,* E. C. FrankLIN,** and D. ZUCKER-FrankLIN, New York. 
5. Recruitment of Anergic Patient's Lymphocytes for Cell Mediated Cytotoxicity by a Specific Antibody. R. M. Blaese, E. B. Rosenberg, and J. R. Wunderlich,* Bethesda, Md.

6. Cellular Immunity and Serum Blocking Activity in Human Renal Allograft Recipients. Leonard J. QUADracci,* Ingegerd E. Hellström,* Gary E. Striker,* Thomas L. Marchioro,* and KarL E. Hellström,* Seattle, Wash. (introduced by Belding H. Scribner).

\section{METABOLISM}

8:00 p.m., Music Room, Chalfonte

Dr. Jean D. Wilson, Presiding

1. Cyclic AMP-Mediated Changes in Na-K ATPase from Rat Kidney Cortex. I. W. WeIss,* S. C. Harris,* S. J. Downing,* and J. M. Phang, Bethesda, Md.

2. The Metabolism of Mevalonic Acid by the Kidney. P. Raskin and M. D. Siperstein,** Dallas, Tex.

3. Polyol Pathway Activity in Aorta: Quantification and Concomitants of Increased Activity. A. D. Morrison and A. I. Winegrad,* Philadelphia, Pa.

4. Woman's Disease: Demonstration of Lipid Accumulation and Acid Lipase Deficiency and Their Apparent Correction In Vitro in Cultured Fibroblasts. E. C. Kyriakides,* Betty Paul,* and J. A. Balint,** Albany, N. Y.

5. Alterations in Oxygen Transport and Red Cell Metabolism As a Consequence of Hypophosphatemia in Intravenous Hyperalimentation. H. Sugerman, S. Travis,* T. Pollock,* R. Ruberg, S. Dudrick,* M. DelivoriaPapadopoulos,* L. Miller,* and F. Oski, Philadelphia, Pa.

6. Differential Modification of Primary and Secondary Insulin Release from Rat Pancreas. I. BURR,* E. MarLIss,* Y. Kanazawa,* A. Lambert,* and A. E. Renold,** Nashville, Tenn., and Geneva, Switzerland.

\section{NEOPLASTIC DISEASE}

8:00 p.m., Garden Room, Haddon Hall

\section{Dr. Joseph R. Bertino, Presiding}

1. Histocompatibility Studies in Patients with Choriocarcinoma. R. H. Rudolph* and E. D. Thomas, Seattle, Wash.

2. Treatment of Gram Negative Septicemia in Granulocytopenic Patients with Normal Granulocyte Transfusions. R. G. Graw, Jr., G. P. Herzig,* H. Eyre,* I. Goldstein,* E. S. Henderson, and S. Perry,** Bethesda, Md.

3. Deranged Intranuclear Ribosomal RNA Processing in Phytohemagglutinin Stimulated Chronic Lymphocytic Leukemia Lymphocytes. A. D. Rubin, E. Schultz,* and S. Davis,* New York.

4. Daunorubicin Metabolism in Acute Myelogenous Leukemia. D. H. Huffman,* R. S. Benjamin,* and N. R.
BACHUR,* Baltimore, Md. (introduced by Jerome B. Block).

5. Pulmonary Function Changes in Patients Treated with Bleomycin. Charles S. LaMonte,* Alan Yagoda,* and IRWIN H. KRAKOFF, ** New York.

6. Effects of Treatment on Total Body Tumor Cell Num. ber in Multiple Myeloma. Sydney E. Salmon and Peter W. Sullivan,* San Francisco, Calif.

\section{PULMONARY}

$$
\text { 8:00 p.m., Seaside Motel }
$$

Dr. Ronald F. Coburn, Presiding

1. Lung Surfactant: Amino Acid Incorporation into Protein of Surface Active Lung Fraction. K. DickIE, G. Massard,* and D. Massaro, Washington, D. C.

2. Comparison Between the Metabolic Effects of Phagocytosis and Phospholipases in Alveolar Macrophages. F. Sachs,* R. Pascual,* R. Bell,* I. Mosher,* S. Motoyama,* and J. B. L. Gee,** New Haven, Conn.

3. Effect of Penicillamine on Fibrous Proteins of Rat Lung. Lee Hoffman,** Olga O. Blumenfeld,* Robert B. Mondshine,* and Sung S. PARK,* Bronx, N. Y.

4. Effects of Thrombolytic Therapy on Pulmonary Perfusion and Diffusion in Pulmonary Embolism: Advantages over Heparin. G. V. R. K. Sharma,* V. A. Burleson,* B. B. Roggeveen,* and A. A. Sasahara,** Boston, Mass.

5. Alveolar Cell Injury from Paraquat. Kaye H. KilburN and Wayland McKenzie,* Durham, N. C.

6. Ultrastructure of Lung Transplants. N. BECKER,* S. Blumcke,* S. Sinha,* and F. J. Veith, New York.

\section{RENAL AND ELECTROLYTES}

\section{8:00 p.m., Rutland Room, Haddon Hall \\ Dr. Thomas F. Ferris, Presiding}

1. Presence of an Angiotensin Forming Enzyme in Brain Tissue of Dogs. D. Ganten, J. Minnich, P. Granger, K. Haydur, A. Barbeau, R. Boucher, and J. Genest, Montreal, Canada.

2. Absence of Mineralocorticoid Effect on Sodium Reabsorption in the Proximal Tubule of Dogs. R. E. LyNCH,* E. G. Sch neider,* T. P. Dresser,* L. R. Willis, and F. G. Knox, Columbia, Mo.

3. Epinephrine Effect on Cyclic $3^{\prime}, 5^{\prime}$-AMP in Kidney. N. P. Beck,* S. W. Reed,* B. B. Davis, and H. V. MurDAUGH,** Pittsburgh, $\mathrm{Pa}$.

4. A Possible Role of Adenyl Cyclase in the Regulation of Parathyroid Activity by Calcium. L. R. Dufresne,* R. Andersen,* and H. J. Gitelman,** Chapel Hill, N. C.

5. Regulation of Renal Medullary Ammonia Production. A. David Goodman, Albany, N. Y.

6. Urea Transport in the Proximal Convoluted Tubule and the Descending Limb of Henle. JuнA P. Kokко,* Dallas, Tex. (introduced by F. C. Rector, Jr.). 


\title{
The Association of American Physicians
}

\author{
84TH ANNUAL MEETING
}

TUESDA Y, MA Y 4

\section{OR N I N G}

9:00 a.m., Pennsylvania Room, Haddon Hall

\section{GENERAL BUSINESS}

THE PRESIDENT'S ADDRESS: Ludwig W. Eichna

(The presentation of each paper will be limited to 12 min.)

1. Long-Term Juvenile Diabetes and Unmeasured Diet. Harvey C. Knowles, JR., Cincinnati.

2. Increased CSF Pressure During Therapy for Diabetic Acidosis. R. S. Clements, Jr.,* S. A. Blumenthal,* A. D. Morrison,* and A. I. Winegrad,* Philadelphia (introduced by Francis C. Wood).

3. Osmotic Equilibrium Between Extracellular Fluid and Cerebrospinal Fluid During Treatment of Hyperglycemic, Hyperosmolar, Non-Ketotic Coma. H. J. CARRoll* and A. I. ARIEFf,* Brooklyn (introduced by Ludwig W. Eichna).

4. Insulin/Glucagon Ratio. R. UnGER,* W. MULLER,* and G. FaloonA,* Dallas (introduced by Marvin D. Siperstein).

5. Studies on the Pathogenesis of Iodide Myxedema. L. E. Braverman,* A. G. Vagenakis,* C. A. Wang,* F. Maloof,* and Sidney H. Ingbar, Boston.

6. Immune Responses in Stroma and Basement Membranes of the Graves' Disease Thyroid (IgM, IgE, IgG, and complement). Sidney C. Werner,* O. Wegelius,* and K. C. Hsu,* New York.

7. Studies in Familial Thyroid Cancer. K. E. W. Melvin,* A. H. TAsh JiAn, JR.,* and H. H. Miller,* Boston (introduced by Edwin B. Astwood).

8. Hyperparathyroidism in Idiopathic Hypercalciuria: Primary or Secondary? F. L. Coe,* J. M. Canterbury,* and ERIC Rerss, Chicago.

9. The Mechanism of Activation of Hormone-Sensitive Lipase. J. K. Huttunen,* R. Heller,* and Daniel SteinberG, La Jolla.

10. Transketolase Inhibition as a Mechanism in Uremic Neuropathy. K. Lange,* E. T. Lonergan,* M. Semar,* and R. B. Sterzel,* New York (introduced by Rachmiel Levine).

\section{A F T ER NOON}

2:00 p.m., Pennsylvania Room, Haddon Hall

\section{PRESENTATION OF}

\author{
THE GEORGE M. KOBER MEDAL \\ TO W. BARRY WOOD, JR.
}

BY

\section{CARL V. MOORE}

11. Pathogenesis of Post Influenzal Collapse of the Lungs of Mice. Clayton G. Loosli, Los Angeles.

12. Evolutionary Aspects of Bacterial Resistance to Chloramphenicol. W. V. ShAw,* Miami (introduced by Harvey Blank).

13. Action of Cholera Toxin to Stimulate Adenyl Cyclase. G. W. G. Sharp,* S. Hynie,* L. C. Lipson,* and D. PARKInson,* Boston (introduced by Alexander Leaf).

14. A Renal Lipid Inhibitor of Erythropoietin. Allan J. Erslev, L. A. Kazal,* and O. P. Miller,* Philadelphia.

15. Evidence for Anti-Leukocyte Antibodies as a Mechanism of Drug-Induced Agranulocytosis. P. A. McIntYre,* Y. Laleli,* B. Hodkinson,* and Henry N. Wagner, Jr., Baltimore.

16. Total Cell Associated Immunoglobulin and Immunoglobulin Synthesis of Human Leukocytes. R. Longmire,* R. McMillan,* R. Yelenosky,* and Charles G. CradDOCK, Los Angeles and La Jolla.

17. Rosette Formation, a Test for Cellular Immunity. J. Wybran,* H. H. Fudenberg, and Marvin H. Sleisenger, San Francisco.

18. Allogeneic Marrow Grafting Using HL-A Matched Donor-Recipient Sibling Pairs. E. Donnall Thomas, J. I. Bryant,* C. D. Buckner,* R. A. Clifft,* A. Fefer,* P. J. Fialkow,* D. D. Funk,* P. E. Neiman,* R. H. Rudolph,* S. Slichter,* and R. Storb,* Seattle. 


\section{E V E N I N G}

6:30 p.m., Garden Room, Lounge Floor, Haddon Hall 7:30 p.m., Vernon Room, Lounge Floor, Haddon Hall

ADDRESS: Robert J. Glaser

\section{THE CHANGING DIMENSIONS OF THE PROBLEMS OF MEDICINE}

WEDNESDA Y, MA Y 5

9:00 a.m., Windsor Room, Haddon Hall

\section{ELECTION OF OFFICERS AND NEW MEMBERS}

THE DISTINGUISHED LECTURE

\section{MECHANICS AND ENERGETICS OF THE NORMAL AND FAILING HEART}

BY

\section{EUGENE BRAUNWALD}

19. Glucose Intolerance in Cardiacs Without Myocardial Ischemia and Its Relation to Cardiac Output. P. O. ETtinger,* H. A. Oldewurtel,* V. Sethi,* and T. J. Regan,* Newark (introduced by Francis P. Chinard).

20. Objective Evaluation of Aortico-Coronary Vein By-Pass Surgery. C. R. Conti,* E. PAGe,* J. O. Humphries,* B. Pitt,* and Richard S. Ross, Baltimore.

21. Functions of Renal Papilla. Louis Tobian, JR. and S. AzAR,* Minneapolis.

22. Coupling of Hypotensive and Anti-Parkinson Effects with Two Dopaminergic Drugs. S. E. DüBY,* L. K. DAHL,* and George C. Cotzias, Upton, N. Y.

23. Metabolism of Adenosine-5'-Monophosphate During Circulation through the Lungs. J. W. RYAN* and U. Smith,* Miami (introduced by William J. Harrington).

24. Hyperoxaluria and Bowel Disease. W. H. Admirand,* D. Earnest,* and H. Williams,* San Francisco (introduced by Rudi Schmid).

25. Effect of Tryptophan on the Hepatotoxic Effects of A1cohol and $\mathrm{CCl}_{4}$. M. A. Rothschild,* M. Oratz,* and S. S. Schreiber,* New York (introduced by Saul J. Farber).

To be read by title

(Members[§] listed alphabetically)

26. Effect of Collagen on the Fibrinolytic System. A. M. Engel and Benjamin Alexander,§ New York.

27. Osteomalacia and Neurofibromatosis: Part of Syndrome of Medullary Thyroid Carcinoma, Hyperparathyroidism and Pheochromocytoma. Frederick C. BartTer, $\S$ C. S. Delea, J. R. Gill, JR., and W. C. Hammond, Bethesda.

28. Abnormal Bile Composition in Prairie Dogs with DietInduced Cholesterol Gallstones. D. E. BRenneman, W. E. Connor, E. L. Forker, and L. DenBesten, Iowa City (introduced by W. B. Bean§).

29. Results of Bypass Grafting for Coronary Artery Disease. E. Glassman, F. C. Spencer, G. Green, D. Tice, and B. Weisinger, New York (introduced by I. Bennett§).

30. Mechanism of Improved Glucose Tolerance on High Carbohydrate Diets in Normals and Mild Diabetics. R. L. Lerner, J. D. Brunzell, W. R. Hazzard, D. Porte, Jr.. and E. L. Bierman,§ Seattle.

31. Studies on the Coronary Microcirculation. R. J. BING, $\S$ K. Hellberg, and A. Rickett, Pasadena.

32. Radioimmunoassay of Plasma Vasopressin in Man. G. L. Robertson, Chicago (introduced by Morton D. Bogdonoff§).

33. Cholesterol Gallstones and Defective Biliary Lecithin Excretion. J. A. Balint, D. A. Beeler, D. H. Treble, and E. C. Kyriakides, Albany (introduced by S. Bondurant§).

34. Unimportance of the Carotid Sinus in the Control of Left Ventricular Contractility. S. F. VATNER, C. B. Higgins, D. Franklin, and E. Braunwald, $\S$ San Diego.

35. Studies in Experimental Chronic Glomerulonephritis: a Clue to the Functional Differences Between Glomerular and Non-Glomerular Disease. H. Lubowitz, D. Mazumdar, J. Crosson, D. Rolf, F. Germuth, and N. S. BRICKER,§ St. Louis.

36. The Renal Medulla and the Antihypertensive Function of the Kidney. E. E. Muirhead, B. Brooks, G. B. Brown, B. E. Leach, L. W. Byers, and J. A. Pitcock, Memphis (introduced by D. A. Brody§).

37. Benefits and Risks of Physical Training of Coronary Patients. R. A. Bruce, $\S$ J. M. Detry, M. Rousseau, and L. A. Brasseur, Seattle and Louvain.

38. Carbohydrate and Nitrogen-Sparing. T. T. Aokı, W. A Muller, E. B. Marliss, and George F. Cahill, Jr.,\$ Boston.

39. Role of the Intestine and Liver in the Metabolism of Folinic Acid Fed to Man. V. M. Whitehead, R. Pratt, A. Viallet, and B. A. Cooper, Montreal (introduced by Douglas G. Cameron§).

40. Coagulant Effects of Puff Adder Venom. L. L. Phillips, L. Pessar, H. J. Weiss, and N. P. Christy, § New York.

41. An Observation on the Etiology of Health. Alvin F. Coburn,§ R. M. Grey, and S. M. Rivera, Tobago, West Indies.

42. Local and Systemic Hypercatabolism of Third Complement Component (C3) in Rheumatoid Arthritis (RA). S. Ruddy, Hans J. Müller-Eberhard, $\S$ and K. Frank Austin,§ Boston and La Jolla. 
43. The Bias Introduced in Therapeutic Trials by Randomization Without Prognostic Stratification. A. R. FEINstern§ and J. R. Landis, West Haven.

44. Evaluation of Factors Regulating Hepatic Extraction of Insulin (HEI). M. Kaden, R. Curtin, L. Carey, F. TAYlor, and James B. Field,§ Pittsburgh.

45. A Working Hypothesis For the Pathophysiology of Kaliopenic Nephropathy. J. B. LeE and H. KanNEGIESSER, St. Louis (introduced by T. F. Frawley§).

46. Fetus and Placenta: Separate Determinants of Maternal Fuel Hemostasis. B. E. Metzger, J. W. Hare, and NorBERT Freinkel, $\S$ Chicago.

47. Acquired Lazy Leukocyte Syndrome. L. E. SpItLeR, L. Petz, P. Spath, and H. Hugh Fudenberg, $§$ San Francisco.

48. Erosive Gastritis-Frequent Source of Upper Gastrointestinal Bleeding in Liver Cirrhosis. J. KHodadoost, D. Katz, and G. B. Jerży Glass,§ New York.

49. Improved Treatment For Metastatic Breast Cancer. C. S. Gordan,§ A. Halden, Y. Horn, and R. Walter, San Francisco.

50. Idiopathic Hypogeusia : a New Syndrome. R. I. Hen Kin, P. J. Schecter, R. Hoye, and C. F. T. Mattern, Bethesda (introduced by R. S. Gordon, Jr.§).

51. Structural Differences in Thyroglobulin as a Cause of Heterogeneity in Thyroid Iodine Turnover. I. KoBAyASHI and M. A. Greer,§ Portland.

52. The Regulation of Human Interferon and Its High Level Production. M. Ho, Y. H. TAN, and J. A. Armstrong, Pittsburgh (introduced by W. McD. Hammon§).

53. Assessment of Etiology of Pulmonary Disease of U. S. Coal Miners. Harriet L. Hardy $\S$ and J. D. Stoeckle, Boston.

54. NA/CA Ratio and Blood Pressure. H. G. LANGFoRd, R. L. Watson, and B. H. Douglas, Jackson (introduced by Harper K. Hellems§).

55. Functional Capacity of the End-Stage Kidney in Man. R. Matalon, P. Deutsch, and R. P. Elsinger, New York (introduced by J. Hirsch§).

56. Phagocytosis of Mycoplasma Pulmonis by Mouse Peritoneal Macrophages. T. C. Jones, S. YEH, and JAMES G. Hirsch,§ New York.

57. Biochemical Properties of Proteinpolysaccharide Complexes in Fresh Human Osteoarthritic Cartilage. D. S. Howell, $\S$ R. D. Altman, J. C. Pita, J. F. Madruga, and F. J. Muller, Miami.

58. Bilirubin Secretion in Intrahepatic Pigment Lithiasis. R. H. Palmer, Y. C. Tsai, M. F. Lin, and C. C. Wen, Chicago and Taiwan (introduced by Leon O. Jacobson§).

59. Permeability Characteristics of the Human Gastric Mucosa: the Absorption of Acid in Ulcer Disease. M. Chapman, J. L. Werther, J. Rudick, and H. D. JanowITz, $\$$ New York.

60. Evolution of an Urban Heroin Epidemic and Influence of a Drug Treatment Program. R. L. DuPont and T. E.
Piemme, Washington (introduced by Wallace N. Jensen§).

61. Stimulation of Human Hemoglobin Synthesis, in vitro by Metabolites of Sex Steroids. R. D. Levere and $H$. MizogUcHI, Brooklyn (introduced by A. Kappas§).

62. Quantitation of Serum Secretory IgA in Gastrointestinal Disease. P. Asquith, R. A. Thompson, and W. T. Cooke, Birmingham, England, and Chicago (introduced by J. B. Kirsner§).

63. Osteopenia and Fractures Occurring During Maintenance Hemodialysis: Another Form of Renal Osteodystrophy. A. M. Parfitt, S. G. Massry, A. T. WinFIEld, and C. R. Kleeman,§ Los Angeles.

64. Lymphocytotoxic Antibodies in Systemic Lupus Erythematosus and Other Connective Tissue Disorders. W. T. Butler, J. T. Sharp, R. D. Rossen, K. K. Mittal, and M. D. Lidsky, Houston (introduced by Vernon Knight§).

65. Elevated Serum Triiodothyronine in Association With Altered Available Iodide in Normal and Hyperthyroid Subjects. C. S. Hollander, N. Nihei, T. Mitsuma, C. Scovill, and M. C. Gershengorn, New York (introduced by $\mathrm{H}$. Sherwood Lawrence§).

66. Alveolar Surface Stability. D. J. Hurst, K. H. KILBURN, and William S. Lynn,§ Durham.

67. The African Pygmies Revisited. D. L. Rimoin, T. J. Merimee, and L. L. Cavalli-Sforza, Boston and Torrance (introduced by V. A. McKusick§).

68. Human Chromosomal Variants: Ultrastructure and Dry Mass. H. M. Golomb, G. F. Bahr, and D. S. BorgaonKAR, Washington and Baltimore (introduced by V. A. McKusick§).

69. Bone Cell Calcium in Metabolic Bone Disorders. G. Nichols, JR.§ and B. Flanagan, Boston.

70. "Febrile" Proteinuria. H. C. Alpert, C. Lohavichan, J. I. Presser, and Solomon PApper,§ Miami.

71. Obfuscation of Susceptibility by Culture Media. P. D. Hoeprich, A. L. BARry, and P. D. FinN, Davis (introduced by Philip Y. Paterson§).

72. Initial Medical Care Utilization in an Experimental Group Practice. G. T. Perkoff§ and J. M. Dickler, St. Louis and New York.

73. The Proliferative Defect of Chlorpromazine Sensitive Marrow Cells. A. V. Pisciotta, $\S$ N. Pawlowski, L. Peterson, and E. Lieberthal, Milwaukee.

74. New Form of Circulating Insulin in Islet Cell Carcinoma. P. Gorden, P. Freychet, and H. NANKIN, Bethesda (introduced by J. E. Rall§).

75. Prostaglandin- and Isoproterenol-Induced Changes in the RBC Membrane. J. E. Allen and H. Rasmussen,§ Philadelphia and Cambridge, England.

76. Transpulmonary Capillary Transport in Pulmonary Edema Related to Increased Permeability. Eugene D. Robin,§ J. Acevedo, and F. Glauser, Stanford.

77. Thrombosis and Acute Myocardial Infarction. A. Fletcher, N. Alkjaersig, O. Owens, G. Wolff, and John R. Sмith,§ St. Louis. 
78. The Sources of Circulating Triiodothyronine in Man. I. J. Chopra, J. H. Dussault, D. A. Fisher, and D. H. Solomon, $\S$ Torrance and Los Angeles.

79. A New Theory of the Course of Development of Myocardial Disease. I. Starr, $\S$ A. NoordergraAf, and P. Verdouw, Philadelphia.

80. Erythroid Aplasia: an Autoimmune Complication of Chronic Lymphocytic Leukemia? Frederick Stohlman, Jr.,§ P. J. Quesenberry, D. Howard, M. E. Miller, and $\mathrm{P}$. SCHUR, Boston.

81. Seasonal Incidence of Lethal Action of Penicillin in Guinea Pigs. Lewis Thomas§ and D. McGregor, New Haven.

82. Cell Wall Defective Bacterial Forms in Patients with Arthritis. P. Charache and A. B. McKusick, Baltimore (introduced by Philip A. Tumulty§).
83. Nonspherocytic Hemolytic Anemia, High Red Cell ATP and Ribosephosphate Pyrophosphokinase (RPK, E. C. 2.7.6.1) Deficiency. W. N. Valentine, $\S$ H. M. Anderson, D. E. Paglia, E. R. Jaffe, P. N. Konrad, and S. R. Harris, Los Angeles.

84. Effect of Hemoglobin Little Rock on the Physiology of Oxygen Delivery. P. A. Bromberg, F. Padilla, J. T. GuY, and S. P. Balcerzak, Columbus and Little Rock (introduced by J. V. Warren§).

85. Association of Red Cell Transport Defect and a Diminished Number of Ouabain Binding Sites. F. WEI, R. Burgos, T. Maynard (by invitation), and L. G. Welt,§ Chapel Hill.

86. Central Neural Mechanisms in Sinus Arrhythmia. W. C. Bond, C. Bohs, J. Long, T. E. Bynum, and Stewart WoLf,§ Galveston. 


\section{Exhibitors}

Booth No.

B3 Academic Press, Inc.

D7 Advanced Instruments, Inc.

H4 American Instrument Co.

B4 Appleton-Century-Crofts

H5 Cambridge Nuclear Radiopharmaceutical Corp.

A4 Clinical Assays, Inc.

C10, C11 Coulter Electronics, Inc.

F4 F. A. Davis Co.

F10, F11 Electronics for Medicine, Inc.

G4 Excerpta Medica Foundation

C4 Gilford Instrument Labs., Inc.

E3 Grune \& Stratton, Inc.

D11 Harper \& Row Publishers, Inc.

G10, G11 Instrumentation LaboRatory Inc.

A5 Intercontinental Medical Book Corp.

H6 Kalmedic Instruments

E5 LEA \& FEBIGER

C1 J. B. Lippincott Co.

D5 Little, Brown \& Co.

D9 The London Company
Booth No.

A3 The Macmillan Co.

D10 McGraw-Hill Book Co.

E11 Micromedic Systems, Inc.

A7 The C. V. Mosby Co.

E1, E2 Nen Biomedical Assay Laboratories Div.

G3 Nikon Div. EPOI INc.

F3 Oxford University Press

B10, B11 Packard Instrument Co.

E9 Pharmacia Laboratories Inc.

C3 Precision Systems, Inc.

D3, D4 W. B. Saunders Co., Div. of CBS, Inc.

A6 Schwarz/Mann, Div. of Becton, Dickinson \& Co.

D8 Ivan Sorvall, Inc.

A8 Springer-Verlag New York, Inc.

E10 Swifta Data Retrieval Company

E7 Year Book Medical Publishers

E8 Vertek INC.

D9 The Williams \& Wilkins Co.

Special

Area Coca-Cola USA 